\title{
MANIFESTATIONS OF IMPLEMENTATION OF THE CSR CONCEPT IN THE RETAIL BANKING SECTOR IN POLAND
}

\author{
MAŁGORZATA KIEŻEL
}

University of Economics in Katowice, Department of Marketing Management and Tourism, POLAND

e-mail: malgorzata.kiezel@ue.katowice.pl

\section{RECEIVED \\ ACCEPTED \\ JEL \\ CLASSIFICATION}

KEYWORDS

ABSTRACT

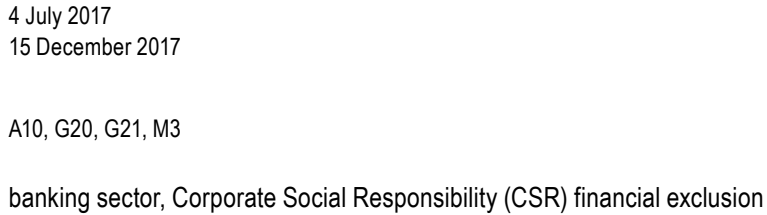

Sustainable development as a process aiming at satisfaction of development aspirations of the present generation, in the way enabling next generations to achieve the same goals is based on three pillars - society, environment and economy. Financial sector and banks that enable exchange transactions to be conducted with the use of various forms of money are particularly important in this process. The purpose of the paper is to identify the manifestations of actions conducted by retail banks that constitute the expression of implementation of corporate social responsibility concept. Thanks to performed studies, it has been stated that the entities of the sector, more and more frequently commence activities supporting implementation of the assumptions of CSR. All analyzed banks used indirect actions, although not in the same range.

\section{Introduction}

Sustainable development as the basis for formation of healthy economy should lead to social cohesion. Financial institutions, including banks, that enable performance of exchange transactions with the use of various forms of money are particularly important in this process. In the banking sector, the entities must face the question of whether it is more important that the main goal should be the maximisation of profit for shareholders through fast 
growth and dividend, or maybe it should be based on an unwritten agreement in which the needs of many stakeholders ought to be taken into consideration. Appropriate bank operations that fit well with the concept of CSR can contribute, among others, to preventing financial exclusion and educating, activating employees, supporting social actions also decreasing environment degradation. The purpose of the paper is to identify the manifestations of actions conducted by retail banks that constitute the expression of implementation of corporate social responsibility concept.

\section{The concept of sustainable development and relationships with corporate social responsibility - literature review}

The notion of sustainable development was defined in 1987 in "Our common future" report of UNO World Commission on Environment and Development as a process that "meets the needs of the present without compromising the ability of future generations to meet their own needs" (Dahlsrud, 2008). While planning effective strategy of achievement of sustainable development, the following three primary areas should be considered: nature protection and effective management of resources, economic growth and fair division of resulting profits, social development (Freeman, Hasnaoui, 2010).

Ecological aspect of sustainable development represents the process of reduction of environmental degradation, constant improvement of its condition and implementation of integrated environment systems, as well as development and implementation of ecological policy. Civilisation aspect means the process of searching for, and implementation of modern technologies, search for new energy sources, and social communication and implementation of new forms of non-economic activity of the society. Social aspect implies development and implementation of social policy, whereas the economic one forces the necessity to develop and implement the strategy and policy of state development. Spatial aspect justifies the need of innovative approach to spatial planning and formation of spatial policy, whereas the political and institutional one obligates to observe the principles of the discussed development in politics and management (Jabłoński, 2005).

Some researchers, e.g. Ch Laszlo (2008, p. 34) use the notions of corporate responsibility and sustainable development interchangeably. He notices that in the case of both notions, the guiding principle is the care about stakeholders and the assessment of the impact that products and enterprise operations have, with respect to their good (Borys, 2005, p. 38-49). At the same time, it must be stated that the concept of sustainable development refers not only to business activity, but also concerns the attitudes of governments, local government units, all state institutions and the whole society. On the other hand, CSR concept focusses on a specific organisation and constitutes both some philosophy, as well as a set of tools allowing for achievement of the condition of sustainable business that, apart from environmental and social benefits, guarantees long-lasting growth of enterprises in a long term (Stefańska, Śmigielska, 2013, p. 491-502).

According to K. Davis and R. Blomstrom (1975), CSR should be approached as the obligation of a corporation management to choose such decisions and actions that will contribute both to taking care about their own interest, as well as protection and growth of social well-being. CSR should also have strategic and long-term dimension, based on the principles of social dialogue and search for solutions beneficial both for the enterprise, as well as its whole environment, workers and all stakeholders (Kowalczewski, 2008, p. 322-323).

Corporate social responsibility also means that in the enterprise, the managing staff chooses such decisions and actions that contribute to taking care about own interest of the entity, i.e. multiplying profit, as well as protection and growth of social well-being". Social responsibility is "the practice of going beyond legal regulations (obligations) 
for effective balancing of obligations towards investors, customers, other enterprises and other communities" (Carroll, 1998).

Despite ambiguities, it is possible to show three common elements. They are justice - taking into consideration the rights of the poorer and future generations, long-term point of view in application of the caution principle, and systemic way of perceiving the sustainable development that enables understanding of mutual relationships between the environment, economy and society (Jeżowski, 2005, p. 59).

\section{Method}

Contribution of commercial banks to sustainable development can be implemented in a direct and/or indirect way (Korenik, 2013). In the first case, it may be achieved through observance of regulations concerning protection of environment, labour and employment, natural resources, pollution emission, co-financing of pro-ecological investments and those that are important for the society, establishment of mutual relationships with customers based on trust, development of the offer for social groups excluded from the market of financial services, and providing services to disabled people. On the other hand, actions of indirect nature include organisation of trainings and information campaigns for workers and society, co-financing actions of ecological and social (non-profit) organisations, development of corporate volunteering programs and participation in ecological and social programs (Łukasiewicz-Kamińska, 2011).

Documentation method comprising the analysis of secondary sources from the studied sector are applied in the paper. The analysis of the literature of the subject is conducted in theoretical part for the purpose of general explanation of basic categories. The study included 12 of the 19 leading commercial banks in 2017 activity based on art. 70 ust. 2 of the law on financial instruments trading (www.knf.gov.pl) - the largest banks in terms of assets. The analysis was carried out on the basis of materials available on the banks' websites. Each of banks declares the implementation of the idea of corporate social responsibility. Research focuses on the identification of indirect forms of CSR implementation. The results were ranked in three groups due to the area of activity: educational for clients and other external stakeholders, training and activating staff (internal stakeholders), and social and ecological.

\section{The role of sustainable development and corporate socia responsibility in banking sector - results}

Sustainable development of financial sector consists in reconciling economic growth with secure and effective diversification of entities providing varied financial services of substitution or complementary nature functioning in it that are intended for various groups of clients, with frequently different preferences that are determined, among others, by the level of income, inclination to risk-taking or age (Ostrowska, 2007, p. 314). Banks are entities that similarly to other enterprises are oriented on profit generation through serving their target markets (Cichy, Gradoń, 2016). At the same time, in comparison with a typical enterprise, banks are burdened with larger obligation to act in socially responsible way. It is expressed by perceiving banks as institutions of public trust, associated with high standards of operation, professionalism, honesty and responsibility (Dziawgo, 2009, p. 126).

Banks, as enterprises rationally managing the capital which constitutes their basic activity, should also have positive contribution to sustainable social and economic development. It is associated with ancillary function of banks expressed in aiming at social well-being through satisfying social and individual needs of society members who are not bank owners (shareholders). This means that society expects from an individual commercial bank that it should provide equal and fair access to its offer (products and financial services) and will positively affect the 
shaping of social and economic order (Korenik, 2009, p. 144). For this purpose, banks should maximise savings of households and enterprises, manage risk with due diligence, allocate savings safely and monitor corporate order. In other words, contemporary banks should affect the society in such a way that they could develop, refine the method of organisation, and improve material standard, which contributes to future achievement of high level of wealth (Flejterski, 2007).

The idea of sustainable development is closely related to the concept of corporate social responsibility (CSR). Major areas of social responsibility of banks result from fulfilment of ancillary obligations, care about interests of private owners (bank shareholders), and observance of human rights, through suitable protection of customer and development of product with a view of their needs, contribution to creation of well-being, prevention of financial and social exclusion, creation of workplaces, care about workers and their families, care about natural environment and observance of law regulations and principles of ethics among others. Such a moral approach to business should relate to strategic instruments of consumer law and demand (Briefing Paper Compendium, 2009).

Activities in the sphere of social responsibility are accompanied by the principles that are not imposed by law, but shaped under strong social pressure. They concern, among others, social dialogue and workers' representation. Furthermore, it is expected from the banks themselves that they should put pressure on their customers and contractors to follow the principles of CSR. The principles should also be helpful in voluntary development of various forms of socially responsible banking that better meet the needs of contemporary society and economy and in ensuring sustainable development.

\section{Examples of implementation of the assumptions of corporate social responsibility by retail banks in Poland - resullts}

An enterprise based on sustainable and permanent development (sustainable corporation) is an economic organisation aiming at expanding long-term value for shareholders through integration of economic, ecological and social opportunities focused on increase of the value in the strategy of the company (Paliwoda-Matiolańska, 2009, p. 242). The results were ranked in three groups due to the area of activity: educational for clients and other external stakeholders, training and activating staff (internal stakeholders), and social and ecological.

Table 1. Indirect activities for the implementation of CSR

\begin{tabular}{|c|c|}
\hline Type of actions & Banks / manifestations of activities \\
\hline 1 & 2 \\
\hline 1. & PKO BP \\
\hline $\begin{array}{l}\text { Educational programs } \\
\text { for clients and society }(A)\end{array}$ & $\begin{array}{l}\text { Bankomania.pkobp.pl. educational and tutorial portal } \\
\text { "Bankowiki" - compendium economic terms } \\
\text { "Bankomania" - quarterly for clients } \\
\text { "Brawo Bank" - economic guide for children }\end{array}$ \\
\hline $\begin{array}{l}\text { Actions for staff and } \\
\text { employee volunteering (B) }\end{array}$ & $\begin{array}{l}\text { PKO after hours - incl. first aid training to people with disabilities } \\
\text { Employee volunteering } \\
\text { The "PKO Bank Polski. Let's run together" }\end{array}$ \\
\hline $\begin{array}{l}\text { Financing and/or } \\
\text { participation in social } \\
\text { and ecological actions (C) }\end{array}$ & $\begin{array}{l}\text { The PKO Bank Polski Foundation: } \\
\text { Cooperation in educational programs with schools and academic centers - e.g.: Olympiad of Economic Knowledge, } \\
\quad \text { cooperation with the Wroclaw University of Technology } \\
\text { Partner of sporting events, especially running ones } \\
\text { Patronage of the National Museum in Warsaw }\end{array}$ \\
\hline
\end{tabular}




\begin{tabular}{|c|c|}
\hline 1 & 2 \\
\hline 2. & Bank Pekao \\
\hline (A) & - \\
\hline (B) & $\begin{array}{l}\text { "Help each other' campaign" - aid program for ill children of bank employees } \\
\text { Blood donation }\end{array}$ \\
\hline (C) & $\begin{array}{l}\text { "Earth Hour" action support, "Protection of Polish bison" action support } \\
\text { Bank Pekao SA Foundation. name of M. Canton: e.g.: } \\
\text { "Gift Matching" Program, "Bank Pekao Project Room" CSW in Warsaw, "Tansman Festival" } \\
\text { Supporting social initiatives "Social Start Up" }\end{array}$ \\
\hline 3. & Bank Zachodni WBK \\
\hline (A) & $\begin{array}{l}\text { Santander Universidades } \\
\text { Finansiaki.pl - children's financial education } \\
\text { BAKCYL - banks' program for youth financial education } \\
\text { "How do you drive", "Around the Wheel" - driver's education }\end{array}$ \\
\hline (B) & $\begin{array}{l}\text { Employee volunteering: Mikolajki in community centers, charity events, food and school supplies, educational and } \\
\text { cultural trips for children from orphanages, blood donation and bone marrow donors registration, help for families } \\
\text { affected by poverty and unfortunate random events }\end{array}$ \\
\hline (C) & $\begin{array}{l}\text { BZ WBK Foundation - programs: Bank of Children's Smile, Bank of Ambitious Youth, Bank of Young Sport Champions } \\
\text { "Tu mieszkam tu zmieniam" } \\
\text { "Two sides of the network" - program in cooperation with the Police } \\
\text { "Passion, Integration, Safety" - fencing integration and educational shows }\end{array}$ \\
\hline 4. & mBank \\
\hline (A) & $\begin{array}{l}\text { "m like math" - program for mathematics education, including: grants, grant program "mPotega", scholarship program } \\
\text { "Masters of Mathematics" }\end{array}$ \\
\hline (B) & $\begin{array}{l}\text { Projects for employees: Bank Talents 2016, People stand out, "Sharing knowledge". } \\
\text { "Let's do something good together" Employee Volunteering Program, } \\
\text { "Do not throw, because he will come back" - anti-smoking program }\end{array}$ \\
\hline (C) & Network security campaign \\
\hline 5. & ING Bank Śląski \\
\hline (A) & $\begin{array}{l}\text { "Społeczność ING" (“Community ING" previously forum and blog Zafinansowani.pl) } \\
\text { loan guides at www.ingbank.pl } \\
\text { BAKCYL } \\
\text { ChallengingIT, ING International Talent Programme, Corporate Readiness Certificate - programs for students and } \\
\quad \text { graduates }\end{array}$ \\
\hline (B) & $\begin{array}{l}\text { Ecological actions: Earth Day, We save paper, Give back the phone } \\
\text { Educational campaigns: World Water Day, Environmental Protection Day, Eco-responsible competition } \\
\text { OFF Culture - the project supports the Environmental Program (sustainable management of office space) }\end{array}$ \\
\hline (C) & Educational paths as part of "Smile Turns" \\
\hline 6. & Bank Millenium \\
\hline (A) & $\begin{array}{l}\text { Financial Elementary - financial education of preschoolers } \\
\text { Cooperation with AIESEC, SKN Statistics, SGH Club of Partners } \\
\text { Educational programs for students and graduates: Millennium Bankers, Akademia Millennium, People Grow, Expert } \\
\text { Start Up }\end{array}$ \\
\hline (B) & $\begin{array}{l}\text { Ecological Guide } \\
\text { Millennium Active Zone program - stimulating an active lifestyle } \\
\text { Employee volunteering - planting trees, charity runs, charity auction } \\
\text { Millantrop program - grants for the implementation of social actions reported by the Bank's employees }\end{array}$ \\
\hline (C) & $\begin{array}{l}\text { Bank Millennium Foundation } \\
\text { Partner of the Kompas Młodej Sztuki } \\
\text { Millennium Docs Against Gravity Film Festival } \\
\text { Patron of culture } 360^{\circ}\end{array}$ \\
\hline 7. & BGŻ BNP Paribas \\
\hline (A) & $\begin{array}{l}\text { Scholarship program "Class" } \\
\text { Scholarship program "Agrotalenty" } \\
\text { BAKCYL }\end{array}$ \\
\hline
\end{tabular}




\begin{tabular}{|c|c|}
\hline & 2 \\
\hline (B) & $\begin{array}{l}\text { "Prestige" - program of development of managerial talent } \\
\text { Days of professional mobility, Outplacemen program } \\
\text { Employee volunteering "You can rely on me", "Good kilometers" program } \\
\text { CSR Days - blood test, first aid workshops, meetings with a nutritionist, Workshop on people with disabilities service }\end{array}$ \\
\hline (C) & $\begin{array}{l}\text { "Konto z Serduszkiem" - a free package of products and services for local NGOs } \\
\text { The mamBONUS program - clients support the "Class" scholarship program } \\
\text { BGŻ BNP Paribas Foundation - participation in the following projects: Finances and Insurance without Barriers, Youth } \\
\text { and Philanthropy }\end{array}$ \\
\hline 8. & Alior Bank \\
\hline (A) & $\begin{array}{l}\text { educational programs for children - popularizing knowledge on entrepreneurship and finance in cooperation with the } \\
\text { Ekomini Foundation } \\
\text { "Matematyk w Banku" - lectures and workshops with the Faculty of Mathematics and Computer Science of the } \\
\text { Jagiellonian University }\end{array}$ \\
\hline (B) & - \\
\hline (C) & - \\
\hline 9. & Getnin Noble Bank \\
\hline (A) & - \\
\hline (B) & $\begin{array}{l}\text { Employee volunteering for pro-social events, such as the annual Fair Play Run } \\
\text { Running Team Getin Noble Bank SA }\end{array}$ \\
\hline (C) & $\begin{array}{l}\text { Charity project "Getin Children" - support children's hospices } \\
\text { Getin Crew - an action of blood donation }\end{array}$ \\
\hline 10. & Citi Handlowy \\
\hline (A) & $\begin{array}{l}\text { Program "Moje Finanse" and "From Grosik to Złotowka" } \\
\text { Olimpiada Wiedzy o Finansach - Banks in Action } \\
\text { The CSR Ambassadors Program - for students } \\
\text { Responsible Business Academy - CSR conference for students } \\
\text { CSR knowledge contest "More trees thanks to you" }\end{array}$ \\
\hline (B) & $\begin{array}{l}\text { Employee Volunteering Program - participation in projects: World Citi Day for the Community, "Become an Assistant to } \\
\text { St. Nicholas" Action, Integration Trips with Volunteering, Economic Education }\end{array}$ \\
\hline (C) & $\begin{array}{l}\text { Kronenberg Foundation at Citi Handlowy: e.g.: The grant program of the Local CSR Workshop, Protection of cultural } \\
\text { heritage, Roots Program, Recovering of Works of Art, Searching for the grave of Nicolaus Copernicus }\end{array}$ \\
\hline 11. & Idea Bank \\
\hline (A) & - \\
\hline (B) & $\begin{array}{l}\text { Quality Academy program - training program - disabled customer's service, reduction of energy consumption, raw } \\
\text { materials, amount of waste } \\
\text { Employee volunteering - blood donation campaigns, collections for shelters and orphanages, first aid trainings and } \\
\text { amateur rescue teams, football and volleyball league, marathons } \\
\text { "A reader-friendly employer" - propagating readership among employees }\end{array}$ \\
\hline (C) & $\begin{array}{l}\text { Supporting the Foundation of Jolanta and Leszek Czarnecki - scholarship programs for the gifted, support children and } \\
\text { youth affected by injuries and diseases }\end{array}$ \\
\hline 12. & BOŚ Bank \\
\hline (A) & Eko Poland - knowledge portal on environment-friendly \\
\hline (B) & Internal contest titled Ambassador of Ekomarki BOŚ \\
\hline (C) & $\begin{array}{l}\text { BOŚ Foundation } \\
\text { pro-ecological projects: } \\
\text { "Postaw na Słońce" - promotion of microinstallation of renewable energy sources, } \\
\text { "Green Bench" - greening of urban space, } \\
\text { "Brudno Tu" - an inventory of wild dumps in Poland. } \\
\text { pro-health projects for the fight against overweight and obesity } \\
\text { \#Psyzdobywajabank }\end{array}$ \\
\hline
\end{tabular}

Source: own study. 
In recent years in Poland the banking sector has taken many actions in the sphere of financial education that is approached as an indirect form of bank contribution to implementation of CSR. Financial institutions started, among others, the actions in the sphere of formation of the awareness of responsible investments and provision of knowledge necessary to make decisions limiting financial risk - the loss of control over transactions and loss of the capability to repay the loans (Frączek, 2014, p. 34; Cohen, Lee, 2008).

\section{Limitations}

Despite growing interest of banks in the concept of sustainable development and corporate business responsibility, global financial crisis showed that the actions often were not conducted the consequent ones. Excessive focus on short-term profit and lack of responsibility for ecological and social damage was predominant among the banking sector entities. Declarative approach to the issue of social responsibility and sustainable development was accompanied mainly by conducting activities aiming at fulfilment of obligations only towards the shareholders because of economic criteria, and assuming only law-related obligations towards society. It is convergent with elementary attitude of social obligation that is generally based on goals of the economic nature. The sector entities that apart from legal and ethical obligations also undertake charity-related activities, assume the attitude of social reaction. The attitude of social contribution in which the performance of the role of the subject that actively looks for the possibility of actual contribution to improvement of general social prosperity is the highest level of social responsibility (Korenik, 2009).

\section{Conclusions}

Implementation of corporate social responsibility is manifested in continuous involvement of banks in honest and responsible behaviours in the face of growing tensions and social problems. Through provision of appropriate services/products, relationships with workers and investments in real sphere of economy, banks can affect employment, quality of labour and quality of relationships with customers. Appropriate actions contribute to improvement in the condition of natural environment and education of the society. This, in turn, translates into development of the social system while improving the quality of life of workers, as well as local communities and the whole society. Banks appreciate the role of these activities. Thanks to performed studies, it has been stated that the entities of the sector, more and more frequently commence activities supporting implementation of the assumptions of CSR. All analyzed banks used indirect actions, although not in the same range.

\section{References}

Borys, T. (2005). Wskaźniki zrównoważonego rozwoju. Warszawa-Białystok: Ekonomia i Środowisko.

Briefing Paper Compendium on Financial Services Issue 2008-2009 (2009). Brussels: European Parliamentary Financial Services.

Buła, P. (ed.) (2010). Współczesne problemy przedsiębiorczości w małych i średnich przedsiębiorstwach. Kraków: Krakowska Szkoła Biznesu Uniwersytetu Ekonomicznego.

Carroll, A.B. (1998). The Four Faces of Corporate Citizenship. Business and Society Review, 1.

Cichy, J., Gradoń, W. (2016). Innovative economy, and the activity of financial market institutions. Case of Poland. Journal of International Studies, 9 .

Cohen, M., Lee, J. (2008). No customer left behind: financial education for long-term adoption of branchless banking. Microfinance Insights, 8. 
Dahlsrud, A. (2008). How corporate social responsibility is defined: an analysis of 37 definitions. Corporate Social Responsibility and Environmental Management, 15, 1.

Davis, K., Blomstrom, R. (1975). Business and Society: Environment and Responsibility. McGraw-Hill Inc.

Dziawgo, L. (2009). Status instytucji zaufania publicznego we współczesnej bankowości: pomiędzy Partnership Banking a Killer Banking. Zeszyty Naukowe Uniwersytetu Szczecińskiego, 548.

Flejterski, S. (2007). Zastosowanie kategorii kapitał do analizy rozwoju regionalnego i lokalnego. Zeszyty Naukowe Uniwersytetu Szczecińskiego, Ekonomiczne Problemy Usług, 11 (2).

Frączek, B. (2014). Main purposes and challenges in the financial education of financial consumers in the world. Journal of Economics \& Management, 16,35 .

Freeman, I., Hasnaoui, A. (2010). The meaning of Corporate Social Responsibility: The Vision of Four Nations. Journal of Business.

http://www.rp.pl/Opinie/303089834-Agenda-2020-dla-sektora-bankowego.html\#ap-3 (10.06.2017).

Jabłoński, J. (2005). Program zrównoważonego rozwoju regionu podkarpackiego. In: B. Poskrobko, S. Kozłowski (eds.), Zrównoważony rozwój. Warszawa: PAN Komitet "Człowiek i Środowisko.

Jeżowski, P. (2005). Rozwój zrównoważony we współczesnych koncepcjach ekonomicznych. In: B. Poskrobko, S. Kozłowski (eds.), Zrównoważony rozwój. Warszawa: PAN Komitet "Człowiek i Środowisko.

Korenik, D. (2009). O roli służebnej banków komercyjnych. Wrocław, Wydawnictwo UE we Wrocławiu.

Korenik, D. (2013). Rola instytucji i rynku finansowego w świetle celów oraz zasad zrównoważonego rozwoju. Prace Naukowe UE we Wrocławiu, 311.

Kowalczewski, W. (2008). Zarządzanie organizacjami w teorii i praktyce. Warszawa: Difin.

Laszlo, Ch. (2008). Firma zrównoważonego rozwoju. Warszawa: Studio Emka.

Ostrowska, E. (2007). Zrównoważony rozwój sektora finansowego w Polsce. In: Spółdzielcze kasy oszczędnościowo-kredytowe charakterystyka, rozwój, otoczenie. Sopot: FnrzPZK.

Paliwoda-Matiolańska, A. (2009). Odpowiedzialność społeczna w procesie zarządzania przedsiębiorstwem. Warszawa: C.H. Beck.

Stefańska, M., Śmigielska, G. (2013). CSR as a source of competitiveness of distribution channels. Zeszyty Naukowe SGGW: Polityki Europejskie, Finanse i Marketing, 9 (58), 491-502.

Cite this article aS: Kieżel, M. (2018). Manifestations of implementation of the CSR concept in the retail banking sector in Poland. European Journal of Service Management, 1 (25), 117-124. DOI: 10.18276/ejsm.2018.25-14. 